\title{
9. China as a Global Investor
}

\section{David Dollar}

China's economic rise is one of the factors creating strains in the international financial order. China is already the largest trading nation and the secondlargest economy, and it is likely to emerge in the next few years as the world's largest net creditor. Currently in second place, China had an estimated $\$ 2.4$ trillion in net foreign assets by the end of 2015, compared with Japan's $\$ 3.6$ trillion. Increases in net foreign assets come through current account surpluses. In the four years ending in 2015, China's cumulative current account surpluses amounted to about \$1 trillion-far larger than Japan's \$200 billion. If those trends continue, it is simple arithmetic that China will become the largest net creditor around 2020.

While China is already the second-largest net creditor, the pattern of its external assets and liabilities is unusual. In mature creditors such as Germany and Japan, private companies and households hold most of the foreign assets. In China, on the other hand, the most important foreign asset has been international reserves accumulated by the central bank, mostly invested in US Treasury bonds and similar instruments. In the past couple of years, however, this pattern has started to change.

China's reserves peaked at about $\$ 4$ trillion at the end of 2014. Since then, the People's Bank of China has sold some reserves, but the country as a whole is still accumulating net foreign assets, as evidenced by the large current account surplus. What is new is that the overseas asset purchases are coming from the private sector and state enterprises, not from the official sector. The Institute for International Finance estimated that the net private capital outflow from China was $\$ 676$ billion in 2015 (an estimate that includes outward investments by China's state enterprises, which, strictly speaking, are not 'private'; the point is to distinguish between official holdings of foreign assets at the central bank and more commercial transactions) (Donnan 2016). As investment opportunities diminish in China, owing to excess capacity and declining profitability, this commercial outflow of capital is likely to continue at a high level.

1 David Dollar is a Senior Fellow in the John L. Thornton China Center at the Brookings Institution. Helpful suggestions on an earlier draft came from my Brookings colleagues Barry Bosworth, Bruce Jones, Homi Kharas, Ken Lieberthal, Eswar Prasad and Mireya Solis. My research assistant, Wei Wang, prepared the data and graphs. Gail Chalef provided important assistance in preparing the chapter for publication. My research on Chinese investment in Africa is supported in part by a grant from the Carnegie Corporation of New York. Brookings recognises that the value it provides is in its absolute commitment to quality, independence and impact. Activities supported by its donors reflect this commitment. The views in the chapter are my own. 
Much of the commercial outflow consists of direct investment (greenfield investments plus mergers and acquisitions). China's Ministry of Commerce (MOFCOM) is the best source of information about the breakdown in China's overseas direct investment. Chinese officials refer to outward direct investment as ODI to distinguish it from inward direct investment. This chapter will use that convention. MOFCOM reports the annual outflow of ODI and the accumulating stock of China's outward investment. Frankly, its numbers seem a bit low given the macroeconomic estimates of capital outflow from China. In recent years, MOFCOM has reported ODI flows a bit above $\$ 100$ billion per year, accelerating to above $\$ 200$ billion in 2014 . The cumulative stock roughly tripled between 2010 and the end of 2014, reaching nearly $\$ 900$ billion (Figure 9.1).

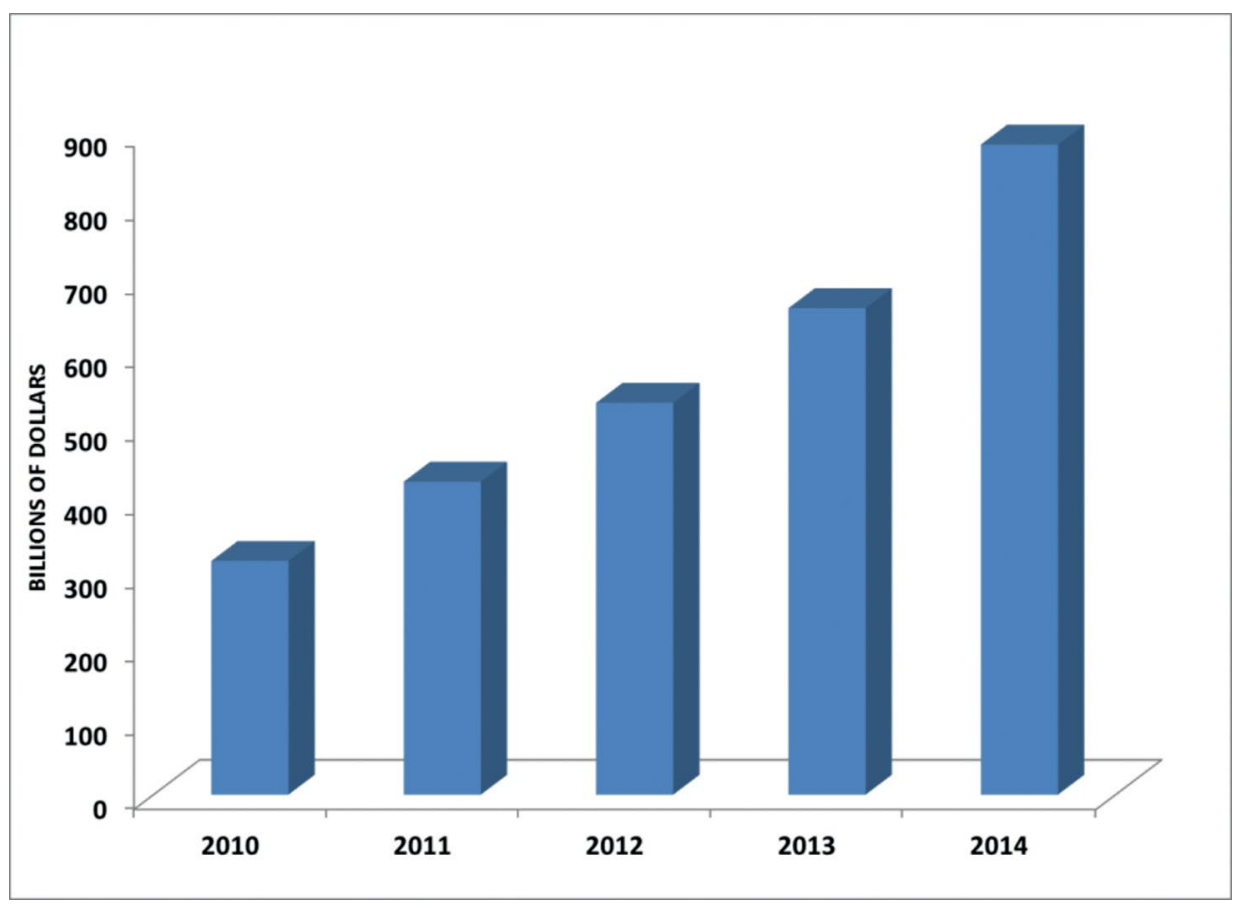

Figure 9.1 The stock of China's ODI expands rapidly

Source: Ministry of Commerce of China (2014).

MOFCOM also reports the allocation of ODI to major recipient economies. About half of China's ODI goes to Hong Kong. This is almost certainly not the ultimate destination for all of this investment; China should work to improve its statistics to reflect the ultimate destination of its overseas investments. One of the obvious recommendations of this chapter is that China makes an effort to improve the statistics on its ODI. There is ample evidence that this is one of the important developments in the world economy today: the emergence of China as the world's largest creditor, with a significant portion of its investment going to 
direct investment. In general, recipient countries welcome direct investment so it would be smart for China to invest in better data that more accurately reflect its role in global investment.

In addition to direct investment, there is significant overseas lending, primarily through the Export-Import Bank of China (China EXIM Bank) and the China Development Bank (CDB). This lending will show up as portfolio investment in the balance of payments. In recent years, each bank has been lending about $\$ 100$ billion overseas. Some of the overseas investment by China takes place under the rubric of the 'One Belt and One Road' (OBOR) initiative. OBOR is Xi Jinping's vision for expanded infrastructure and other investment along the traditional Silk Road route through Central Asia as well as along the maritime route south from China through South-East Asia to South Asia and on to Africa and Europe. However, the actual amounts involved in OBOR investment so far appear small. Looking at the list of the top 10 destinations for China's ODI, leaving aside Hong Kong, the top three are the United States, Australia and the United Kingdom, none of which is involved in OBOR. Also in the top 10 are France, Canada and Germany. Most foreign direct investment (FDI) in the world goes to advanced industrial economies and the same can be said for China's ODI. The only OBORinvolved countries among China's top 10 investment destinations are Russia, Indonesia and Kazakhstan.

That a developing country is emerging as the world's largest investor is an interesting phenomenon that raises the following questions: to what extent is Chinese investment similar to other foreign investment and to what extent, if any, is it challenging global norms and practices? I argue that there are three ways in which Chinese investment differs from the existing norms and practices: 1) Chinese investment is relatively, though not absolutely, concentrated in poor governance environments; 2) China, in general, does not subscribe to global standards of environmental and social safeguards; and 3) China itself remains relatively closed to foreign investment in many sectors, in contrast to its partners in both the developed and the developing worlds. As China gains more experience as a global investor, it is likely that Chinese investment will, in some ways, become more typical, that it will reshape global norms in other areas, but that it may remain at odds with global practices to some extent.

\section{Chinese investment and governance}

China has drawn attention to itself through some large investments in countries that have poor governance, such as the Democratic Republic of the Congo and Angola in Africa and Venezuela and Ecuador in Latin America. At the same 
time, the United States is the single biggest destination for China's ODI, with a stock of $\$ 38$ billion at the end of 2014. This section examines the general relationship between Chinese ODI and governance.

A natural point of departure is the relationship between FDI overall and governance. ${ }^{2}$ The stock of FDI in the world is around \$20 trillion and most of it has come from the Western industrial economies. Much FDI is in fact crossinvestment among advanced economies. Of the 10 largest recipients of FDI, eight are advanced economies: United States, United Kingdom, France, Germany, Canada, Spain, the Netherlands and Australia. The two emerging economies on the list are China (number two after the United States) and Brazil.

The best predictor of how much FDI a country has received is its market size as measured by total gross domestic product (GDP). One of the main motivations of direct investment is to get close to markets to understand demand trends and to provide after-sales services. There is also a certain amount of FDI that is in search of natural resources. This trend is not that strong globally, but it can be important within regions. Among African countries, for example, natural resource rents as a share of GDP are a good predictor of how much FDI a country has received.

After controlling for market size and natural resource wealth, FDI is strongly attracted to better governance environments. Figure 9.2 shows the correlation between the stock of FDI and an index of property rights and the rule of law for 152 countries. The index, from the Worldwide governance indicators, 'captures perceptions of the extent to which agents have confidence in and abide by the rules of society, and in particular the quality of contract enforcement, property rights, the police, and the courts, as well as the likelihood of crime and violence' (Kaufmann and Kraay 2015). The figure shows a partial scatter after controlling for total GDP and natural resources rents. The index has a mean of zero and a standard deviation across countries of 1.0, so that one standard deviation better on rule of law is associated with 62 per cent more FDI. There are other aspects of governance - notably, political indicators such as measures of democracy and civil liberties. In general, measures of political governance and economic governance are highly correlated across countries. In examining investment and growth, economic measures tend to perform better. It makes intuitive sense that the profitability of investment would be higher in an environment of better property rights and rule of law, and that such environments would attract more investment, other things being equal.

2 The data in this section come from Dollar (2015). 


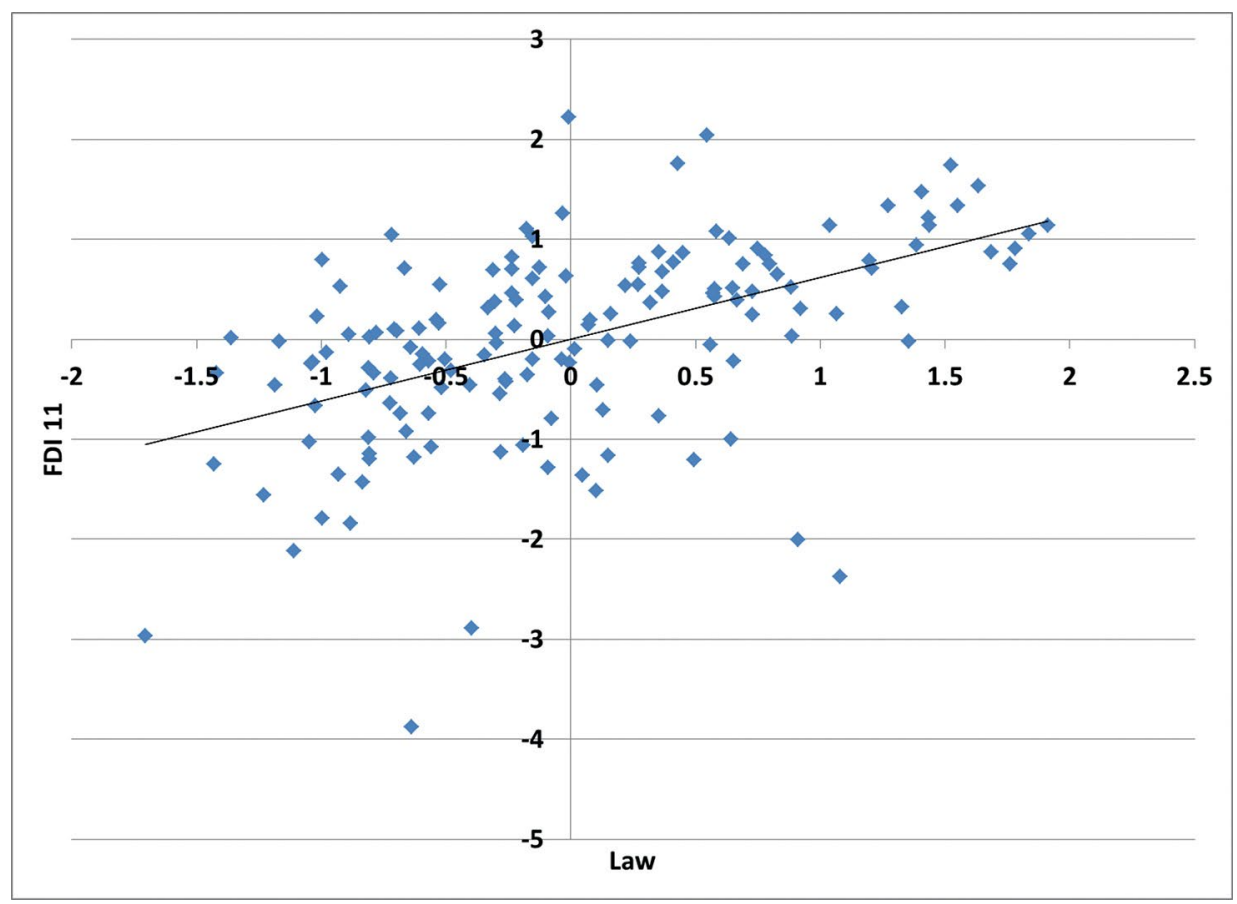

Figure 9.2 Global FDI strongly attracted to good rule of law

Source: Dollar (2015).

Chinese ODI is similar to FDI overall in that it is attracted to larger markets and to natural resource wealth. For ODI, the attraction to larger markets is a bit weaker than for FDI, and the attraction to natural resources is a bit stronger; but basically Chinese investment is similar to other investment. Where Chinese ODI is different is that it is uncorrelated with the index of property rights and the rule of law (Figure 9.3). There is actually a slightly negative relationship between how much ODI a country receives and economic governance, but it is not statistically significant. It would be accurate to say that Chinese ODI appears indifferent to the governance environment. 


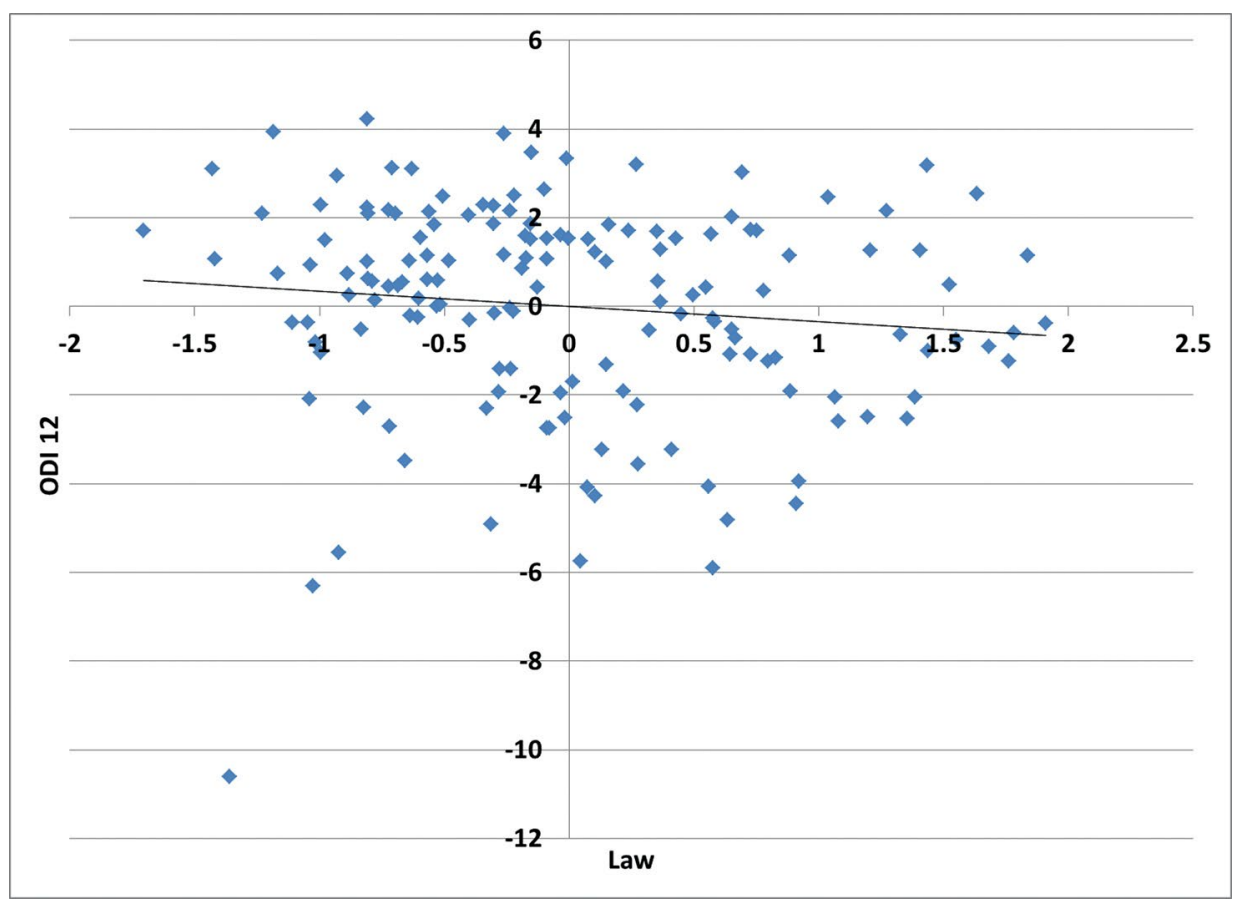

Figure 9.3 Chinese ODI uncorrelated with rule of law

Source: Dollar (2015).

This feature of Chinese investing can be illustrated through some specific examples. In Africa, the largest destination for Chinese investment is South Africa, which has some of the better governance indicators on the continent. But there is also significant Chinese investment in Angola, Democratic Republic of the Congo and Sudan, all of which have poor governance indicators. In Latin America, the largest destination for Chinese investment is Brazil, which is among the better half of the region's countries in terms of rule of law. But there is also significant investment in Argentina, Ecuador and Venezuela. If Latin American countries are divided in half on the basis of rule of law in 2014, 85 per cent of the stock of total FDI is in the better-governed half. For Chinese ODI, slightly more than half is in the poorly governed group. The pattern is similar for lending from the China EXIM Bank and the CDB. Venezuela is the largest recipient in Latin America of loan commitments from the Chinese banks, while Brazil is the second-largest borrower.

The point is not that China is seeking out the poor governance environments. It is a major investor in the well-governed countries that are the largest recipients of FDI globally. But it does appear to be indifferent to the governance environment to the extent that it is making major investments in weak governance environments where other investors fear to tread. There are 
a number of plausible explanations for this pattern of investment. Many of the large investments from China are made by state enterprises. On the one hand, they do not feel the same pressure as private firms to earn good returns on their investments. (It is a clear empirical regularity that state enterprises are less productive and profitable than private ones within China, so it makes sense that this would be the same abroad.) On the other hand, their investments in poor governance environments are often part of state-to-state deals and they may feel insulated from the local economic environment.

It is also the case that China is a relative newcomer on the global investment scene and Chinese firms may have underestimated the risks involved in some investments. There is evidence that some natural resource investments in poor governance environments are turning out badly. In the case of Democratic Republic of the Congo, China's \$6 billion 'minerals for infrastructure' deal was signed in 2007. Chinese firms Sinohydro Corp and China Railway Group Limited agreed to build roads and hospitals in exchange for a 68 per cent stake in the Sicomines copper and cobalt mine - one of the largest in Africa. China's staterun EXIM Bank and smaller Chinese banks put up \$3 billion for infrastructure plus a further $\$ 3$ billion to develop Sicomines, with all the loans to be repaid with mining profits. Yet, eight years on, production from the mine has been delayed as a result of crippling power shortages, suffocating bureaucracy and corruption (Ross 2015). The main lesson from the project is that investing in one of Africa's most chaotic countries is a messy and frustrating business.

In Angola, Sinopec invested in six deepwater oilfields in cooperation with the Angolan state oil group, Sonangol, from 2004 to 2013. The investment has turned into a black hole that has swallowed funds from Sinopec without generating any commercial return. In March 2015, auditors sent by the National Audit Office to screen financial statements of Sinopec International Petroleum and Production, Sinopec's overseas investment arm, found that investments made in the five oilfields during 2008-13 have amounted to about $\$ 10$ billion and that poor performance, exaggerated oil reserve estimates and sharp declines in international oil prices will lead to a majority of the investment going down the drain (Ning et al. 2015). In the case of Venezuela, China has also had to renegotiate loan terms in favour of Venezuela because the country was unable to service the original loan once the price of oil fell.

China's pattern of global investment raises two policy issues, one for China and one for the world. First, from China's point of view, is it getting the best return on its investments? Chinese state enterprises, by definition, are playing with the people's money. If they waste tens of billions of dollars in poor investments, that is a real loss for China. It makes sense that China is emerging as a major global investor at this point in its development because investment opportunities within the country are diminishing and the rapid ageing of the population has 
reduced domestic growth prospects. Earnings on overseas investments could help China finance its public pension system and the safety net more broadly. So it is in Chinese people's interest to have sound management of overseas investment. Based on the domestic experience, the more of the investment that comes through the private sector, the better. A study of the small and medium-sized Chinese enterprises investing in Africa, which are mostly private firms, found interesting differences to the big state-to-state deals. The small and medium-sized firms are not investing in natural resource extraction. Most investments are in services, and a significant number are in manufacturing. The manufacturing investment is influenced by the local endowments of capital and skilled labour, which is consistent with profit-maximising investment (Chen et al. 2015).

From a global point of view, there is the question of whether China's state-tostate financing is sustaining poor governance in some countries. The projects in the worst governance environments may not be returning economic benefits, but China's money is going somewhere. In some countries, Chinese funding is likely supporting corrupt political elites and helping them maintain their hold on power. In the case of Venezuela, for example, in the absence of Chinese finance, the government would have had little choice but to turn to the International Monetary Fund (IMF) and other traditional sources of finance in exchange for policy reforms to stabilise the economy and restore growth.

\section{Environmental and social safeguards}

A second issue raised by China's emergence as a major global investor concerns environmental and social safeguards. China is a major funder of mining and infrastructure projects. Such projects normally carry significant environmental risks and often involve the involuntary resettlement of large numbers of people. So far, China has been reluctant to subscribe to any international standards for environmental and social safeguards. Its position is that it follows the laws and regulations of the host country. This is a reasonable point of view, consistent with China's general position that countries should not interfere in each other's internal affairs. The problem, however, is that the implementation of environmental and social regulations is often weak, especially in the countries with weak governance.

Private financial institutions from Western countries have generally subscribed to international environmental and social standards under the rubric of the 'Equator Principles' (EP). The principles are: 
[A] risk management framework, adopted by financial institutions, for determining, assessing and managing environmental and social risk in projects. It is primarily intended to provide a minimum standard for due diligence to support responsible risk decision-making. Currently, 83 Equator Principles Financial Institutions (EPFIs) in 36 countries have officially adopted the EP, covering over 70 percent of international Project Finance debt in emerging markets. (Equator Principles Association 2011)

Large Chinese banks such as the China EXIM Bank and CDB have not been willing to join. Only one small Chinese bank, the Industrial Bank, has joined so far.

The multilateral development banks (MDBs) that fund infrastructure in the developing world have even more stringent standards. Led by the World Bank, these standards have been developed since the 1990s, primarily in response to pressure from civil society groups in wealthy countries. The safeguards are an area of tension between the rich countries that fund the multilateral banks and the developing countries that borrow from the banks. This tension is captured in a 2015 study by the Intergovernmental Group of Twenty-Four, which was established in 1971 to coordinate the positions of developing countries on monetary and development issues:

One aspect of the business practices of the World Bank and major RMDBs that has a particularly strong impact on infrastructure investment is environmental and social safeguard policies. Safeguards comprise procedures and restrictions on different types of lending operations meant to 'safeguard' the project from having negative impacts on the environment and social groups. Safeguards were first instituted at the World Bank in the 1990s, and the other major RMDBs [regional multilateral development banks] followed suit in subsequent years. The World Bank's safeguards are still considered the most comprehensive and rigorous, but the safeguards of the [ADB: Asian Development Bank], IADB [Inter-American Development Bank], and AfDB [African Development Bank] have been gradually tightened over the years such that the differences between them are relatively small, particularly on the hot-button issues of environmental assessment and resettlement.

As a project undergoes the initial screening process, MDB staff members determine whether it triggers any of the MDB's applicable safeguards. Should that be the case, a separate series of special requirements must be followed before the loan can be approved and disbursed. The most frequently triggered safeguards in the case of the World Bank relate to environmental assessment and involuntary resettlement, and most frequently affect investment projects in the transportation, energy, and urban sectors. The required procedures are extraordinarily detailed and specific, and in many cases (notably, the World Bank's IBRD [International Bank for Reconstruction and Development] and IDA [International Development Association]) extremely difficult for borrowers and 
even staff to fully understand. Requirements often include time-consuming, lengthy studies to be undertaken by third-party experts (usually at the government's cost), lengthy consultations with affected parties (sometimes including unelected non-governmental organizations), extensive mitigations measures, and lengthy mandatory prior public disclosure and comment periods during which time the project cannot move ahead. These requirements supersede whatever national laws may be in place in the borrowing country - a particularly troubling point of principle for many borrowing countries, beyond the practical impacts of safeguards. (Humphrey 2015: 19)

It is fair to say that these procedures developed by the World Bank are the gold standard of environmental and social safeguards in infrastructure projects. However, they have had a number of unintended consequences. It has become time-consuming and expensive to undertake infrastructure projects with the World Bank and, as a result, developing countries have turned to other sources of funding. Infrastructure was the original core business of the World Bank, accounting for 70 per cent of lending in the 1950s and 1960s. That has steadily declined to about 30 per cent in the 2000s. Looked at another way, all of the MDBs together provided about $\$ 50$ billion of infrastructure financing in 2013 well under 1 per cent of total infrastructure spending in developing countries. Hence, the multilateral banks have developed gold-plated standards, but they apply to only a tiny fraction of investment.

Given this situation, the emergence of China as a major funder of mining and infrastructure projects has been welcomed by most developing countries. China is seen as more flexible and less bureaucratic. It completes infrastructure projects relatively quickly so that the benefits are seen sooner. However, China's approach of relying on the recipient country's own laws and regulations also has its risks. In Gabon, Sinopec was found exploring for oil in Loango National Park before any environmental impact study had been undertaken. Several Chinesefunded infrastructure projects on the continent will have large environmental consequences, including the Kongou Dam in Gabon, the Bui Dam in Ghana and the Lower Kafue Gorge Dam in Zambia. All these cases call for careful balance of development needs with environmental risks.

This issue of environmental and social safeguards was a key factor in the brouhaha around the founding of the Asian Infrastructure Investment Bank (AIIB). China proposed the new bank partly in response to its frustration with the slow reform of existing institutions, including the IMF, World Bank and ADB. The new bank is also a way for China to put its excess savings to use through a multilateral format, to complement (and perhaps provide some competition with) its bilateral efforts. The United States opposed the effort, primarily out 
of concerns about governance, including the issue of environmental and social safeguards. Other major Western nations, such as the United Kingdom, Germany, France and Australia, all chose to fight these battles from the inside.

The AIIB has promulgated environmental and social policies that, on paper, are similar to the principles embodied in World Bank safeguards: environmental and social assessments to analyse risks; public disclosure of key information in a timely manner; consultation with affected parties; and decision-making that incorporates these risks. The AIIB approach, however, differs from that of the World Bank by avoiding detailed prescriptions for how to manage the process. My own experience in the World Bank was that the application of safeguards created two problems. First, the detailed regulations-literally hundreds of pages - inevitably made implementation slow and bureaucratic. Second, management tended to be very risk-averse so that the response to problems was often additional study at extra expense. Developing countries have learned not to take complicated, risky projects to the existing banks, when in fact those are exactly the projects where the world would benefit the most from the assistance of multilateral institutions.

The AIIB's website indicates that its environmental and social guidelines should be implemented 'in proportion to the risk'. The AIIB's leadership hopes that the bank can meet international standards but be more timely and cost-effective. This is largely a matter of implementation and it will take experience on the ground and time to see if the effort is a success. The AIIB is the first major multilateral bank in which developing countries have the majority of the shareholding, so it follows that the preferences of the bank will align more with developing than developed countries. This could be a very positive innovation: since most investment and growth now take place in developing countries, it would be more efficient if development bank activities reflected the preferences of those countries. If the AIIB's activities can put pressure on the World Bank and the ADB to streamline their procedures and speed up their infrastructure projects, this would be a positive change to the global system that emanated from China.

\section{Reciprocity}

Most of the major investing countries in the world are developed economies; in addition to making direct investments elsewhere, they tend to be very open to inward investment. China is unusual in that it is a developing country that has emerged as a major investor. China itself is an important destination for foreign investment and opening to the outside world has been an important part of its reform program since 1978. However, China's policy is to steer FDI to particular 
sectors. In general, it has welcomed FDI into most but not all of manufacturing. However, other sectors of the economy are relatively closed to FDI, including mining, construction and most modern services. It is not surprising that China is less open to FDI than developed economies such as the United States. But it is also the case that China is relatively closed among developing countries.

The Organisation for Economic Co-operation and Development (OECD) calculates an index of FDI restrictiveness for OECD countries and major emerging markets. The index is for overall FDI restrictiveness and also for restrictiveness by sector. The measure covers various investment restrictions, the most important of which is equity caps on how much of a domestic enterprise can be owned by a foreign investor. Figure 9.4 shows the restrictiveness index in 2014 for the whole economy and some major industries for Brazil, Russia, India, China and South Africa (the BRICS). Overall, Brazil and South Africa are highly open and similar to advanced economies, with measures around 0.1 (on a scale of $0=$ open and $1=$ closed). India and Russia are less open, with overall measures around 0.2. China is the most closed, with an index above 0.4 .

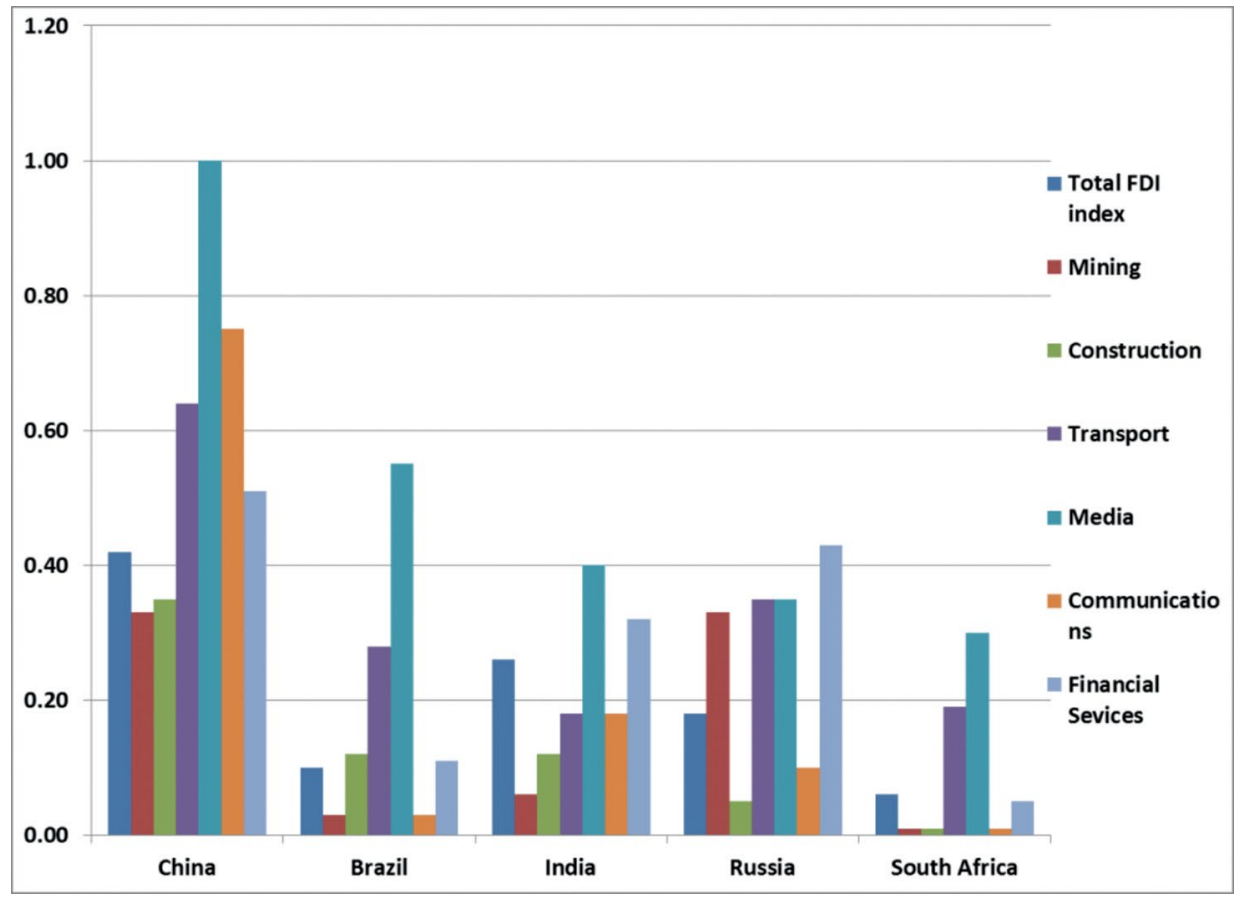

Figure 9.4 China is the most closed of the BRICS ${ }^{*}$ countries (FDI restrictiveness index, 2014)

*BRICS = Brazil, Russia, India, China and South Africa Source: Kalinova et al. (2010). 
The sectors highlighted are some of the more closed ones in China. China's restrictiveness index in mining is 0.33 , compared with an average of 0.11 for the other four; in communications, 0.75 compared with 0.08 ; in financial services, 0.51 to 0.23 ; and so on. Some of the key sectors in which China is investing abroad-such as mining, infrastructure and finance-are relatively closed at home.

This lack of reciprocity creates problems for China's partners. China has the second-largest market in the world. In these protected sectors, Chinese firms can grow unfettered by competition and then use their domestic financial strength to develop overseas operations. In finance, for example, China's four state-owned commercial banks operate in a domestic market in which foreign investors have been restricted to about 1 per cent of the market. The four banks are now among the largest in the world and are expanding overseas. China's monopoly credit card company, Union Pay, is similarly a world leader based on its protected domestic market. A similar strategy applies in mining and telecommunications.

This lack of reciprocity creates an uneven playing field. A concrete example is the acquisition of the US firm Smithfield by the Chinese firm Shuanghui. In a truly open market, Smithfield, with its superior technology and food-safety procedures, may well have taken over Shuanghui and expanded into the rapidly growing Chinese pork market. However, investment restrictions prevented such an option, so the best way for Smithfield to expand into China was to be acquired by the Chinese firm. Smithfield chief executive officer Larry Pope said the deal would preserve 'the same old Smithfield, only with more opportunities and new markets and new frontiers'. No Chinese pork would be imported to the United States, he said, but rather, Shuanghui desired to export American pork to take advantage of growing demand for foreign food products in China due to recent food scandals. Smithfield's existing management team is expected to remain intact, as is its US workforce (Chapman 2013).

The United States does not have much leverage with which to level the playing field. It does have a review process for acquisitions of US firms by foreign ones. The Committee on Foreign Investment in the United States (CFIUS) is chaired by the US Treasury Department and includes US economic agencies (the Department of Commerce and the Office of the US Trade Representative) as well as the Departments of Defence and Homeland Security. By statute, CFIUS can only examine national security issues involved in an acquisition. It reviewed the Smithfield deal and let it proceed because there was no obvious national security issue. CFIUS only reviews around 100 transactions per year and the majority of them proceed. This system reflects the US philosophy of being very open to foreign investment. 
China's policies create a dilemma for its partners. Taking those policies as given, it would be irrational for economies such as the United States to limit Chinese investments. In the Shuanghui-Smithfield example, the access to the Chinese market gained through the takeover makes the assets of the US firm more valuable and benefits its shareholders. Assuming that the firm really does expand into China, the deal will then benefit the workers of the firm as well. It would be even better, however, if China opened up its protected markets so that such expansions could take place in the most efficient way possible. In some cases, that will be Chinese firms acquiring US ones, but, in many other cases, it would involve US firms expanding into China.

This issue of getting China to open its protected markets is high on the policy agenda of the United States and other major economies. The United States has been negotiating with China over a bilateral investment treaty (BIT) that would be based on a small negative list - that is, there would be a small number of agreed sectors that remain closed on each side-but otherwise, investment would be open in both directions. So far, however, negotiations on the BIT have been slow. It is apparently difficult for China to come up with an offer that includes only a small number of protected sectors. And there are questions as to whether the US Congress would approve an investment treaty with China in the current political environment, even if a good one were negotiated.

\section{How is Chinese investment likely to evolve?}

To the extent that Chinese investment differs from global norms and practices, there are three possible paths forward: 1) Chinese investment could become more typical; 2) global practices could shift in the Chinese direction; or 3) China could remain at odds with the rest of the world. This section speculates that we may see some combination of all three options.

First, when it comes to investment in poor governance environments, China is likely to evolve in the direction of current investment norms - that is, to favour better governance environments. Part of China's motivation for investing in countries such as Venezuela and Democratic Republic of the Congo was to access natural resources. In the 2000s, China's growth model was very resource intensive and global prices for most commodities were rising. That made it tempting to look for resources, even in risky environments; however, that has all changed this decade. A lot of new supply has come on line in sectors such as oil and gas, iron and copper. Meanwhile, China's growth model is shifting away from resource-intensive investment towards greater reliance on consumption. Consumption consists primarily of services, which are less resource intensive. As a result of these shifts in supply and demand, commodity prices have come 
down and China's import needs have diminished. Also, as noted earlier, the investments in poor governance countries are not working out well. As Chinese people demand a better return on state-backed investments abroad, it is likely that China will pull back on the resource investments in countries with poor governance. At the same time, many Chinese private firms are looking to invest abroad in a wide range of sectors, and those investments are heading to the United States, other advanced economies and emerging markets with relatively good governance, as is the case with global investment in general.

Concerning environmental and social safeguards for infrastructure projects, China has identified an issue that resonates with other developing countries. The World Bank and other MDBs have been imposing environmental and social standards that reflect the preferences of rich-country electorates. Developing countries have been voting with their feet and have turned away from those banks as important sources of infrastructure financing. In general, they welcome Chinese financing of infrastructure. Developing countries' response to the proposal for a new infrastructure bank, the AIIB, was particularly strong. Asian countries that are not particular friends of China - such as India, Indonesia and Vietnam - were quick to sign up to the effort. The AIIB's attempt to develop workable safeguards to address environmental and social risks without the long delays and high costs of existing MDB practices is an important innovation. This is an interesting example of where China may end up modifying global norms to make them align better with developing-country preferences. It is unfortunate that the United States and Japan have chosen to remain aloof from the effort.

The third issue identified in this chapter - reciprocity - should be an easy one for China. There is ample evidence that big state enterprises are less productive than private firms in China. Many of the sectors that remain closed are service sectors such as finance, telecommunications, transportation and mediaall dominated by large state enterprises. With the shift in China's growth model, these service sectors are now the fast-growing part of the economy, while industry is in relative decline. It will be easier for China to maintain a healthy growth rate if it opens these sectors to international competition, in the same way that it opened manufacturing in an earlier era. And talk of opening these sectors can be found throughout party documents, such as the third plenum resolution. However, actual progress in opening under the new leadership has been slow. It may be difficult for China to commit to any bold opening in the next few years as it grapples with adjustment of its growth model and as it prepares for a political transition in 2017.

It will be natural for a new US administration to take a hard look at United States-China economic relations, especially the emergence of China as the largest net creditor. The massive outflow of capital from China is a new phenomenon 
that was not on the radar screen eight years ago. Furthermore, attitudes in the United States towards China are hardening, and it will be tempting to take a harsher stance on each of the three investment issues analysed here. But taking a hard line across the board would be a mistake as the three issues are evolving in different ways.

First, it is annoying that China is providing finance to regimes with poor governance, some of which are a thorn in the side of the United States. However, there is not much the United States can do about this. And the main destinations for Chinese investment are the same advanced, capitalist countries on which other investors focus. It is likely that Chinese investments in the poor governance environments will continue to do poorly.

Second, on infrastructure investment, China has clearly tapped into an important sentiment in the developing world that infrastructure is key to growth and that private finance and existing development banks are not sufficient. Part of the problem is that the existing banks are not large enough; a second issue is that they have turned away from infrastructure as a core business. On this issue, the smart thing for the United States would be to find a way to say 'yes' to China's standing offer to join the AIIB. More importantly, given the United States' leadership role in the World Bank and regional banks, it should accelerate the governance reform that would strengthen developing countries' shares and roles. If the next president of the World Bank were a successful reformer from the developing world, that would be a powerful statement and a real change. More developing-country voices in the existing development banks are likely to result in their getting back into infrastructure in a major way.

The issue of lack of reciprocity between China's investment openness and the US system is the most worrisome of the trends. A new president will have to take a serious look at the CFIUS process and the enabling legislation and consider what combination of carrots and sticks would accelerate the opening of China's markets. In terms of sticks, the United States could consider amendment to the CFIUS legislation that would limit acquisitions by state enterprises from countries with which the United States does not have a BIT. In terms of carrots, the best move for the United States is to approve the Trans-Pacific Partnership (TPP) and implement it well so that there is deeper integration among likeminded countries in the Asia-Pacific. Success in this will encourage China to open further and eventually meet the high standards set by the TPP. Greater investment openness is part of China's own reform plan but it clearly needs incentives to make real progress. 


\section{References}

Chapman, M. (2013), China's Shuanghui buying Smithfield Foods for about $\$ 4.72$ billion, taking company private, Associated Press, 29 May.

Chen, W., Dollar, D. and Tang, H. (2015), Why is China investing in Africa? Evidence from the firm level, Washington, DC: Brookings Institution.

Dollar, D. (2015), United States-China two-way direct investment: Challenges and opportunities, Washington, DC: Brookings Institution.

Donnan, S. (2016), Capital flight from China worse than thought, Financial Times, 20 January. Available from: ft.com/intl/cms/s/0/ae4dee44-bf34-1le59fdb-87b8d15baec2.html\#axzz46Ns84ERl.

Equator Principles Association (2011), The Equator principles. Available from: equator-principles.com/.

Humphrey, C. (2015), National development banks and infrastructure provision: A comparative study of Brazil, China, and South Africa, Infrastructure Finance in the Developing World Working Paper Series, Washington, DC: Intergovernmental Group of Twenty-Four on Monetary Affairs and Development.

Kalinova, B., Palerm, A. and Thomsen, S. (2010), OECD's FDI Restrictiveness Index: 2010 Update, OECD Working Papers on International Investment, 2010/03, OECD Publishing. Available from: dx.doi.org/10.1787/5km9lp02zj7g-en.

Kaufmann, D. and Kraay, A. (2015), Worldwidegovernance indicators, Washington, DC: The World Bank. Available from: info.worldbank.org/governance/wgi/ index.aspx\#home.

Ministry of Commerce of China (2014), Statistical Bulletin of China's Outward Foreign Direct Investment. Available from: hzs.mofcom.gov.cn/article/ date/201510/20151001130306.shtml.

Ning, Y., Kaixi, H. and Yanwen, Y. (2015), Businessman linked to Sinopec's Angola deals said to face probe, Caixin Online, 14 October. Available from: english.caixin.com/2015-10-14/100862966.html.

Ross, A. (2015), China's 'infrastructure for minerals' deal gets reality-check in Congo, Reuters, 9 July. Available from: reuters.com/article/2015/07/09/uscongodemocratic-mining-china-insight-idUSKCNOPIIUB20150709. 
This text is taken from China's New Sources of Economic Growth: Reform, resources and climate change, Volume 1, edited by Ligang Song, Ross Garnaut, Cai Fang \& Lauren Johnston, published 2016 by ANU Press, The Australian National University, Canberra, Australia. 